\title{
Measles - an old children's disease to remember
}

\author{
Sarampo - uma velha doença infantil a relembrar

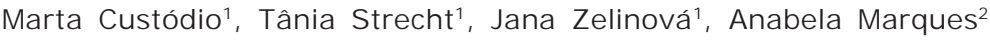

\begin{abstract}
Measles is a serious, highly contagious viral disease. The measles virus is a single-stranded, RNA virus of the genus Morbillivirus within the family Paramyxoviridae, transmitted by air, through droplets of aerosols or by direct contact with respiratory secretions of infected individuals. The infection is acquired through the mucosa of respiratory tract or conjunctiva.

In 2005, the World Health Organization established that measles eradication in the European Region should be achieved by 2010 , but despite the measures adopted by the various countries, measles re-emerged, with 10271 cases reported only in 2013 in 30 states of European Union, with more than $91 \%$ of them in Germany, Italy, Netherland and United Kingdom.

In the beginning of 2017, Portugal was threatened with a measles outbreak, reporting in the first five months of the year 31 confirmed cases, $20(65 \%)$ of them in adults (18 or older), of which $45 \%$ (13) were in health professionals.

Because this measles outbreak had so many cases in adults, the authors decided to make a brief review, trying to remember an old infection, not so well known by younger doctors, and that can be overlooked in the approach of the adult patients.

The authors also point out that measles virus could virtually be eradicated as there is an effective vaccine and there is no reservoir in nature for the virus other than humans.
\end{abstract}

Keywords: Measles. Outbreak. Vaccine, MMR. Vaccination.

\section{RESUMO}

O sarampo é uma doença viral grave e altamente contagiosa.

O vírus do sarampo é um vírus de ARN, cadeia simples, do gênero Morbillivirus, da família Paramyxoviridae, transmitido pelas vias aéreas, através de gotículas de aerossóis ou por contato direto com secreções respiratórias de indivíduos infectados. A infecção é adquirida pelo contato dessas gotículas com a mucosa do trato respiratório ou conjuntiva.

1. Resident of Internal Medicine, Cascais Hospital, Portugal.

2. Internal Medicine Specialist, Cascais Hospital, Portugal

Conflicts of interest: The authors have no conflicts of interest to declare.

Funding source: There were no funding sources.
CoRRESPONDÊnCIA: Marta Custódio Hospital de Cascais, Serviço de Medicina Interna e Especialidades Médicas, piso 6 Avenida Brigadeiro Victor Novais Gonçalves 2755-009 - Alcabideche martaisabelcustodio@hotmail.com

Recebido em 13/11/2017

Aprovado em 10/05/2018 
Em 2005, a Organização Mundial de Saúde estabeleceu que o objetivo para a erradicação do sarampo na Região Europeia seria até 2010 mas, apesar das medidas adotadas pelos diversos países, o sarampo ressurgiu, com 10271 casos relatados somente em 2013 em 30 estados da União Europeia, com mais de 91\% deles na Alemanha, Itália, Holanda e Reino Unido.

No início de 2017, Portugal foi ameaçado por um surto de sarampo, relatando nos primeiros cinco meses do ano 31 casos confirmados, 20 (65\%) em adultos (com idade igual ou superior a 18), dos quais $45 \%$ (13) foram em profissionais de saúde.

Face a este surto de sarampo ter tantos casos em adultos, os autores decidiram fazer uma breve revisão, tentando relembrar uma infeção antiga, não tão conhecida pelos médicos mais jovens e que pode ser esquecida na abordagem de um doente adulto.

Os autores salientam igualmente que o vírus do sarampo pode virtualmente ser erradicado, pois existe uma vacina eficaz e não existe na natureza nenhum reservatório para o vírus, além dos humanos.

Palavras chave: Sarampo. Surtos de Doenças. Vacina SCR. Vacinação.

\section{INTRODUCTION}

Measles is a serious, highly contagious viral disease, ${ }^{1-4}$ remaining worldwide one of the leading causes of death in young children. ${ }^{2,3}$

Humans are the natural hosts and until now no animal reservoirs are known to exist, ${ }^{2,3}$ which makes worldwide eradication of measles achievable, if all the measures are taken, specially vaccination. ${ }^{2-6}$

In some outbreaks one of the leading cause of measles transmission is a delay in the diagnosis (even after rash appearance) due to nonawareness, unfamiliarity of measles in adults and the difficulty in differentiating it from other febrile diseases with rash. ${ }^{7}$ Furthermore, infected people are usually contagious from four days before until four days after rash onset, 1,2,3,5,6 and there is no fast diagnosis test permitting a rapid exclusion of this disease.

Nosocomial transmission is believed to be an important and emerging way of spreading the infection, ${ }^{8}$ so trying to prevent that, the authors make a brief review of this old infection, highlighting its peculiarities, emphasizing the need to maintain adequate vaccination coverage.

\section{INFECTIOUS AGENT}

Measles virus is a single-stranded, RNA virus of the genus Morbillivirus within the family Paramyxoviridae. ${ }^{1-6}$

\section{Epidemiology}

It's a universal disease, ${ }^{3}$ occurring all around the world.

Humans are the natural hosts of the virus and until now no animal reservoirs are known to exist, ${ }^{1,2,3}$ which makes worldwide eradication of measles achievable if all the measures are taken, specially vaccination. ${ }^{1-5,7,8,9}$

Since 2000, when measles was declared eliminated from the United States of America, the annual number of cases has ranged from a low of 37 in 2004 to a high of 667 in 2014. ${ }^{3}$ Nowadays, six European Union/European Region (EU/ER) countries still have endemic transmission: Belgium, France, Germany, Italy, Poland and Romania, ${ }^{6}$ but multiple others are facing outbreaks.

Measles is a highly contagious viral disease, ${ }^{1-9}$ mostly transmitted by direct contact; acquired throughout the mucosa of respiratory tract or conjunctiva, by air droplets of aerosols or contact with respiratory secretions of infected individuals. ${ }^{1-6}$ Transmission by indirect contact with contaminated materials is infrequent but also possible. ${ }^{1}$ The virus can be in the environment for up to two hours. ${ }^{8}$

It's a winter and spring disease, there is traditionally a transmission attached to the places where people cohabit closely, like hospitals, clinics, health centres, churches, schools, among others, 1,10 mostly because in the beginning of the illness the symptoms are mild and people, even 
feeling ill (sometimes already with fever) continue their routines until rash appears, associated with the fact that patients are most contagious four days before up to four days after the appearance of the rash. ${ }^{1,2,3,5,9} \mathrm{I}$ mmunocompromised patient or a patient who took immunoglobulin can spread the virus for a longer time. ${ }^{1-6,9}$

\section{Clinical presentation (figure 1)}

The incubation period (from exposure to onset of fever) ranges from 7 to 21 days (medium 10-11), 1,3,6,9 known to be more prolonged in adults. ${ }^{9}$

The prodromal period (symptomatic period before rash) courses with fever (as high as $40.6^{\circ} \mathrm{C}$ ), conjunctivitis, coryza (nasal congestion, runny nose, sneezes) and cough. Koplik spots are pathognomonic for measles, appears two days before rash, and are characterized by being small spots with white or bluish-white centres on an erythematous base on the buccal mucosa, first near premolars with possibility of generalization to the remaining mucosa. $1,2,3,6,9$

Rash usually emerges about 14 days after exposure. ${ }^{3}$ A characteristic red, maculopapular, coalescent rash, appears on the third to seventh day after the beginning of clinical complaints. ${ }^{3,5,6}$ (figure 2). It has a cephalocaudal distribution, starting on the head and reaching the feet by the third day and lasts four to seven days. ${ }^{1,3,5,6}$

After the disappearance of the rash, there may be a thin furfuraceous scaling.

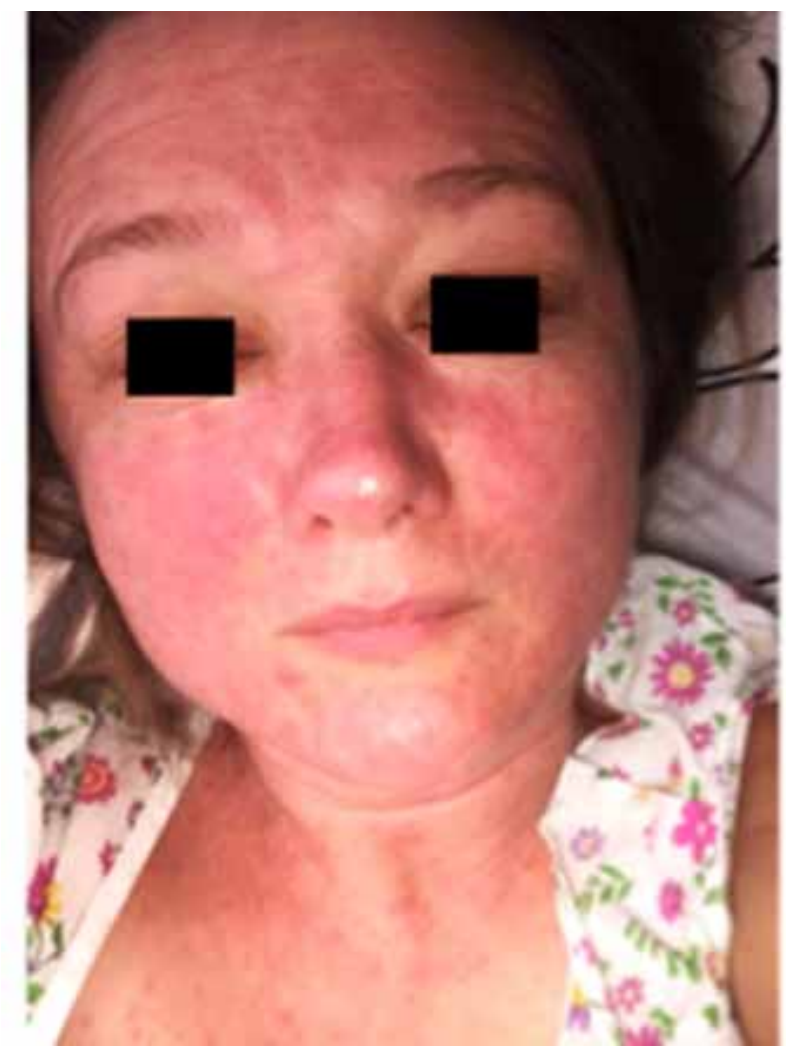

Figure 2: Rash in adult with confirmed measles.

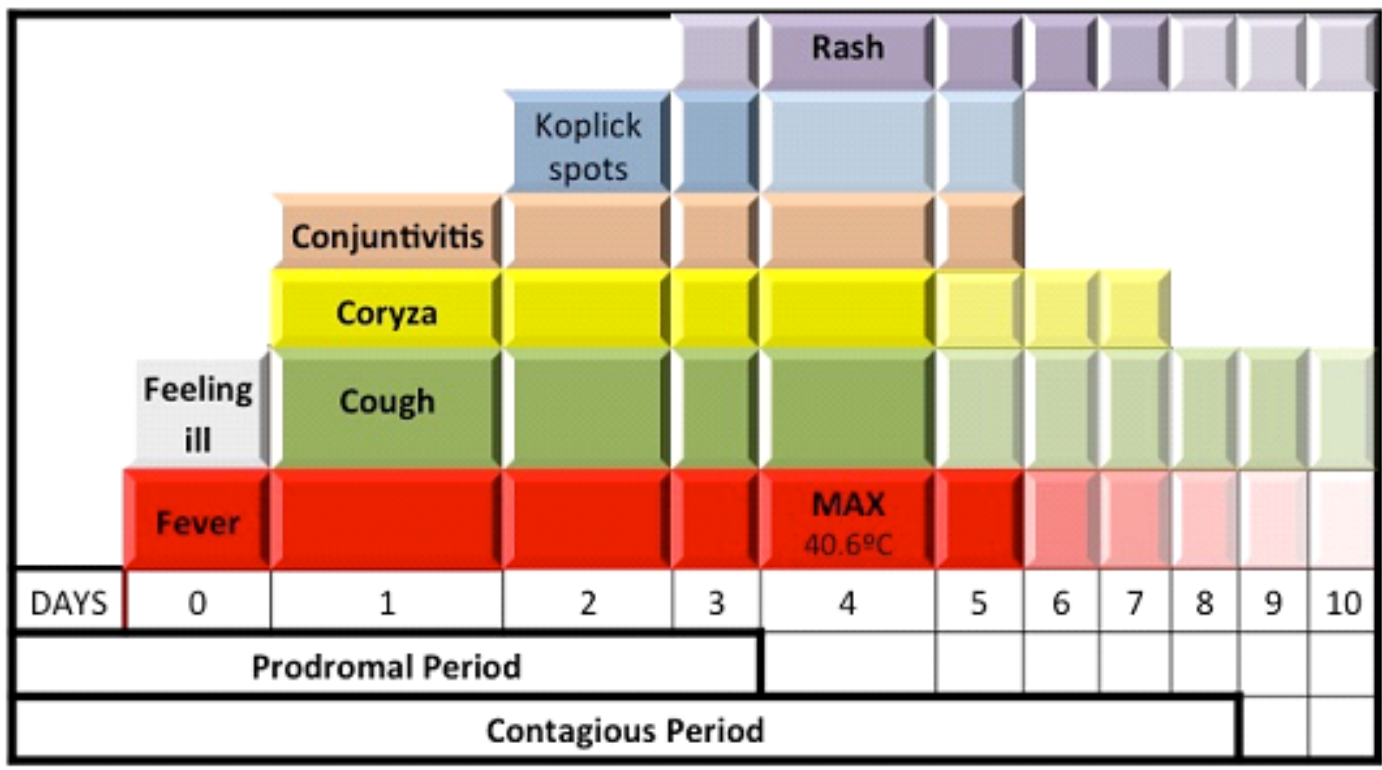

Figure 1: Clinical presentation over time frame. 
Contagious period is between the fourth day before to the fourth day after rash appearance. $1,2,3,5,6$

Generalized lymphadenomegalies is frequent and more evident at the cervical and occipital levels. ${ }^{1}$

In vaccinated patients sometimes symptoms reported are modified or nonclassic. They may have less severe manifestations and/or of shorter duration than what is typically observed in a primary infection, not easily identified if not fit into an outbreak or epidemiological context. ${ }^{11}$

\section{Complications}

May arise from viral replication or bacterial superinfection and may occur during or after the rash. ${ }^{1,5}$ The risk of serious complications and death (1-3/1000 cases) is highest for children aged $\leq 5$ years and adults aged $\geq 20$ years and in patients with poor nutritional status and immunocompromised individuals. ${ }^{1,2,3,5}$

Most common complications include diarrhoea, middle ear infection, pneumonia (accounts for six out of ten measles associated deaths), 1,2,3 among others as laryngitis, myocarditis, pancreatitis and appendicitis. ${ }^{1}$

Encephalitis is rare but can result in permanent brain damage. ${ }^{1,3,5}$ Subacute Sclerosing Panencephalitis (SSPE) is also rare but fatal, generally occurs when measles is acquired earlier in life, developing 7 to 10 years after acute infection. ${ }^{12,13}$

Measles in pregnancy results in high fetal morbidity and mortality, miscarriages and stillbirths. ${ }^{1,2,4,5}$

\section{Diagnosis}

Measles is difficult to distinguish from other causes of febrile illnesses with rash, easily mistaken with rubella, parvovirus B19, human herpesvirus type 6 (HHV-6) and dengue. ${ }^{6}$

Classical clinical diagnostic criteria are fever with maculopapular rash and at least one of the three - cough, rhinitis and/or conjunctivitis. However, it's known that a few cases can seroconvert without experiencing any symptoms. ${ }^{14}$

Laboratory confirmation is essential for the definitive diagnosis of measles and for measures to contain and control outbreaks or sporadic cases, so in possible and probable cases, collec- tion of products for detection of viral RNA by PCR isolation should be done at the same time as the collection for serology. ${ }^{7}$

The detection of viral RNA by PCR is more likely to be positive when the collection is performed early (best on the onset of the rash and up to ten days later); negative results do not invalidate the diagnosis and is mostly important to clarify cases with inconclusive serology. ${ }^{7}$

In some countries, like Brazil, where PCR is not easily available, the serologic diagnosis is enough to confirm infection.

In an unvaccinated patient IgM antibodies to measles virus usually occur in the first one to four days of exanthema, with a peak at the end of the first week after the appearance of the rash and progressively decrease for six to eight weeks.

So it should be collected serology in the first 72 hours after the appearance of the rash, and should be confirmed 72 hours later, to exclude a false negative result. ${ }^{7}$

IgG antibodies rises usually seven to ten days after the onset of the rash and persist throughout life.

In cases of IgM + and IgG + antibodies in the acute phase, a second sample, collected ten or more days after the first, should show a significant increase if it is case of measles. ${ }^{7}$

In cases of IgM + and IgG - antibodies in the acute phase of the disease, a second sample, collected ten days or more after the first, should show elevation of IgG antibodies. If no increase is verified, the IgM + antibody result will have been a false positive. ${ }^{7}$

In vaccinated patients there is often a very attenuated and transient IgM antibody response, so IgM - does not exclude the diagnosis of measles, being the PCR the best method for the confirmation of these cases. ${ }^{7}$

\section{Treatment}

Treatment is supportive. ${ }^{1,2,3,5}$

WHO recommends vitamin A for all children with acute measles, regardless of their country of residence, to reduce the risk of complications. ${ }^{3,15}$

Bacterial superinfections are common and should be treated with antibiotics but prophylactic treatment is not indicated. Continued fever beyond two days after the onset of rash may be an indication of complications. ${ }^{6}$ 


\section{Prevention}

Immunization is considered the most effective measure of prevention against measles. $5,6,8,13$ The vaccine it's a highly effective live attenuated strain vaccine, with an excellent safety profile. ${ }^{16,17}$ Rare adverse events may occur. In adults were register for example anaphylaxis (1-3,5 occurrences per million doses administer) and thrombocytopenia (3-4 cases per 100000 doses). ${ }^{17}$ Until now no evidence supported an association between vaccination with hearing loss, retinopathy, optic neuritis, Guillain-Barré Syndrome, type 1 Diabetes, Crohn's disease or autism. ${ }^{16}$

Vaccination against measles was introduced in the Portugal National Vaccination Plan in 1974, but in 1987 it was changed to trivalent vaccine against measles, mumps and rubella (MMR). By 1990 a second dose was introduced to overcome the $5-15 \%$ failure of the vaccines at the initial dose. ${ }^{2,3,5}$ At this time MMR is administered at 12 months and the second dose at five-six years of age. 5,6

An anti-vaccination movement is a problem emerging all around the world. This and imported cases of measles bring a new obstacle to eradication.

There are outbreaks even between vaccinated populations, being the number of doses of vaccine received, the most important predictor of antibody response. ${ }^{14}$ Because of that, all health professionals should have two doses (The second dose of the vaccine should be administer at least 28 days apart).

After vaccination people can not transmit measles. ${ }^{16}$

People who have had measles are considered to be protected for life, not requiring vaccination, $5,14,18$ but there is the possibility of misdiagnosing this infection with another exanthematic disease. To avoid unnecessary risks in Brazil, all health professionals should be vaccinated regardless history of previous infection.
Post-exposure prophylaxis can be done with vaccine (if administered within 72 hours of initial measles exposure) or with immunoglobulin (if administered within six days of exposure) and may provide some protection or modify the clinical course of disease. ${ }^{1,3,5,6}$

Patients should be isolated, excluding them from community setting (school, hospital, childcare; place of work) until the fourth day after the beginning of the rash. ${ }^{1,3,6}$

Healthcare personnel without evidence of immunity should be excused from duty from day five after first exposure to day 21 after last exposure, regardless of post-exposure vaccine. ${ }^{3,11}$

\section{CONCLUSION}

Measles is an acute, highly contagious disease seen all around the world, at any age and that can be fatal.

Worldwide eradication of measles is theoretical possible because humans are the only virus natural host and a secure vaccine is available.

Vaccination is considered the best way to protect yourself and others against measles, regardless of the age and despite a known vaccine failure.

Recalling this old disease between the health professionals is crucial, aiming for an early identification, preventing transmission and even avoiding progression to an outbreak.

In Portugal measles is an obligatory notification disease done in National System of Epidemiological Surveillance online platform, ${ }^{5}$ being that a tool for health authorities to early identify sporadic cases or outbreaks.

\section{Acknowledgment}

The authors are thankful for the collaboration of Nadia Korchevnyuk, MD by providing the illustrative photography of the measles rash. 


\section{BIBLIOGRAPHY}

1. Dias $P$, Valente $P$, Mota L, Pinheiro M, Mendes A, Doenças Eruptivas Agudas/Sarampo; Temas de Infecciologia Pediátrica vol 1;10-24; Pita Groz Dias Editor; 2a edição 1993.

2. World Health Organization. Measles [fact sheet no. 286]. Geneva: World Health Organization; 2014 [cited 2016 Sep. 25]. Available from: http:// www. who.int/mediacentre/factsheets/fs286/en.

3. Center for Disease Control and Prevention (CDC).

Available from: https://www.cdc.gov/measles/hcp/ index.html and https://wwwnc.cdc.gov/travel/ yellowbook/2018/infectious-diseases-related-totravel/measles-rubeola.

4. Palminha P., Vinagre E., Cordeiro R., Ribeiro C., Roque C.; Diagnóstico Laboratorial do sarampo em Portugal 2011-2013; 2015. Available from: http://repositorio.insa.pt/bitstream/10400.18/ 3240/3/observacoesNEspecia6-2015_artigo6.pdf.

5. Direcção-Geral da Saúde; Norma no 004/2017 de 12/04/2017 atualizada a 26/04/2017 (a partir da norma Norma no 06/2013).

6. European Centre for Disease Prevention and Control (eCDC) - epidemiological update: Measles - monitoring European outbreaks, 22 June 2017 and Facts about Measles. Available from: https:// ecdc. europa.eu/en/news-events/epidemiologicalupdate-measles-monitoring-european-outbreaks22-june-2017 and https://ecdc.europa.eu/en/ measles/facts/factsheet

7. Premaratna R., Luke N., Perera H., Gunathilake M., Amarasena P., Chandrasena N.; Sporadic Cases of adult measels: a reserch article. BMC Res Notes jan 10, 2017 10:38 https://doi.org/ 10.1186/s13104-017-2374-6

8. Porretta A, Quadttrone F, Aquino F, Pieve G, Bruni $B$, Gemignani $G$, et al. A nosocomial measles outbreak in Italy, February-April 2017. Euro Surveill Aug 17, 2017; 22(33). https://doi.org/ 10.2807/1560-7917.

9. Direcção-Geral da Saúde; Boletim epidemiológico: Sarampo em Portugal 29 Maio-4 Junho 2017.

10. Gastanaduy PA, Budd J, Fisher N, Reed SB Fletcher J, Miller J, et al. A Measles Outbreak in an Underimmunized Amish Community in Ohio. N Engl J Med Oct 6, 2016; 375:1343-1354; https:// doi.org/10.1056/NEJ Moa1602295.
11. Rota J., Hickman C., Sowers S.B, Rota P., Mercader S.,Bellini W.; Two Case Studies of Modified Measles in Vaccinated Physicians Exposed to Primary Measles Cases: High Risk of Infection But Low Risk of Transmission; J Infect Dis (2011) 204 (suppl 1): S559-S563. https:// doi.org/10.1093/infdis/jir098.

12. Barrero P.R., Grippo J., Viegas M., Mistchenko A.S.; Wild-type Measles Virus in Brain Tissue of Children with Subacute Sclerosing Panencephalitis, Emerg Infect Dis. 2003 Oct; 9(10): 1333-1336. https://doi.org/10.3201/eid0910.030180.

13. Bellini W.J., Rota J.S., Lowe L.E., Katz R., Dyken P.R., Zaki S.R., et al, Subacute Sclerosing Panencephalitis: More Cases of This Fatal Disease Are Prevented by Measels Immunization than Was Previously Recognized. J. Infect Dis, Vol 192, Nov 15, 2005, (10) 1686-1693, https://doi.org/ $10.1086 / 497169$

14. Gustafson. T.L, Lievens A.W., Brunell P.A., Moellenberg R.G., Buttery C.G., Sehulster L.M.; Measels Outbreak in Fully Immunized SecondarySchool Population. N Engl J Med; Mar 26, 1987; 316:771-774; https://doi.org/10.1056/ NEJ M198703263161303

15. Hussey G.D., M.Sc.(Lond.), Klein M.; A Randomized, Controlled Trial of Vitamin A in Children with Severe Measles. N Engl J Med; July 19, 1990; 323:160-164; https://doi.org/10.1056/ NEJ M199007193230304

16. CDC Measels, Mumps and Rubella Vaccinevaccine use and strategies for elimination of measles, rubella, and congenital rubella syndrome and control of mumps: recommendations of Advisory Committee on Immunization Practices (ACIP). MMWR 1998; 47 (no.RR-8).

17. Strebel P.M., Papania M.J., Dayan G.H., Halsey N.A., Measels vaccine. Plotkin SA, Orenstein WA offit PA, eds. Vaccines 5 th ed. Philadelphia, PA: W.B. Saunders; 2008: 353-98.

18. Atkinson W.L., Markowitz L.E. Adams N.C Seastrom G.R.; Transmission of measles in medical settings - United States, 1985-1989. Am J Med. Sep 16, 1991; 91(3B):320S-324S. https:// doi.org/10.1016/0002-9343(91)90389-F 